\title{
Race, Crime, and Criminal Justice in Portugal
}

\author{
Manuela Ivone Cunha \\ University of Minho, CRIA-UM, Portugal
}

Cunha Manuela P. da (2010), "Race, Crime and Criminal Justice in Portugal", in Anita Kalunta-Crumpton (ed.) Race, Crime And Criminal Justice: International Perspectives, New York, NY, Palgrave MacMillan: 144-161.

Pre-print

\section{Introduction: On Ethnic Foreigners, Immigrants and State Statistics}

Any focus on the issue of ethnicity, crime and criminal justice in Portugal has to take into account two specificities which have comparative implications - not to mention the fact that comparability may be hindered from the start at the more general level of the statistical data infrastructure itself. ${ }^{1}$ First, Portuguese official statistics register only nationalities, not ethnicity or phenotype. Direct or indirect registration by the State of data allowing for the identification of such information is prevented by law in order not to reinforce stereotyping (see Cabecinhas 2007) or the racialization of society ${ }^{2}$. The existence of ethnic/racial minorities is therefore not formally acknowledged by the State, which recognizes only individual citizens. Portuguese citizens thus include, without any ethnic specification, ex-immigrants who have acquired the Portuguese citizenship $^{3}$.

\footnotetext{
${ }^{1}$ Contrary to criminal statistics of other European countries, until very recently Portugal did not have an integrated system of data registration. Each law enforcement department or State bureau had its own data base for internal purposes, without an overall coordination which would establish uniform categories, criteria, and methods. It did not allow either for studying the way a given criminal event is dealt with by the criminal justice system from the moment it is reported until it is tried. The current attribution of a single number to each criminal event (Número Único de Identificação de Processo Crime) is intended to address this issue. Furthermore, in addition to the obstacles surrounding the analysis of officially reported delinquency, it is difficult to circumvent the problem of the dark figures of unreported crime, as victimization and/or self-reported delinquency surveys are still scarce or incipient (Crucho de Almeida 1994, 1998; Gersão and Lisboa 1994). For this same reason, the importance of specific types of criminal victimization such as hate crime is also even harder to assess.

${ }^{2}$ See the 1994 Decreto-Lei 28/94.

${ }^{3}$ In this text I use the words Portuguese / national / Portuguese national to designate those who have Portuguese citizenship, regardless of phenotype, ethnicity (whites, blacks, Gypsies...) or country of birth (Africans who have acquired Portuguese citizenship, for example). 'Foreigners' apply to those who don't have Portuguese citizenship, even if they reside in Portugal.
} 
Second, State crime statistics only have the generic category of foreigners, without distinguishing between residents - whether documented or undocumented - or visitors. Official statistics do not single out immigrants. 'Foreigners' cannot however be used as a proxy category for immigrants as it is wider, including both residents and non residents. As an example of the proportion of convicts in the period 1997-2003, between $1 / 4$ and $1 / 8$ of the convicted foreigners were resident abroad prior to their conviction As an example, between a quarter and an eighth of the convicted foreigners in the period 1997-2003, were resident abroad prior to their conviction (Seabra and Santos 2005: 96).

The numbers of foreigners residing legally in Portugal rose from a mere 0.3 percent $(29,579)$ of the total resident population in 1960 to 3.9 percent $(414,717)$ in 2005, although undocumented residents may currently be between 50,000 and 100,000 (Guia 2008: 39, 53). For a long time Portugal has been a country with consistent emigration trends. But since the 1970s it has also become an immigration country: first following the end of the Portuguese colonial empire and the independence of former colonies that took place after the 1974 democratic revolution; and, later on, in the 1980s and 1990s, with the economic boom and the country's entrance into the European Union in 1986. The end of the former Soviet Union also contributed to shape the landscape of immigration in more recent times (for an overview of the evolution of immigration patterns in Portugal (see Baganha, Marques and Fonseca 2000; Baganha and Marques 2001; Pena Pires 2003).

Initially, the country received mostly Africans from the Portuguese speaking African countries ${ }^{4}$ (especially Angola, Guinea Bissau, Cape Verde, and Mozambique).

\footnotetext{
${ }^{4}$ African countries where the official language is Portuguese are known under the acronym PALOP (Países Africanos de Língua Oficial Portuguesa). Besides the countries mentioned above, they include also S. Tomé e Príncipe.
} 
From the 1990s onwards, the range of nationalities in Portugal was transformed again by a sharp increase of arrivals from Brazil and, a decade later, from Eastern Europe, mostly from Ukraine and Russia. In 2004, 41 percent of the legal foreign residents came from Europe, 34 percent from African countries (mostly from lusophone countries), and 19 percent from Latin American countries (especially Brazil) (Guia 2008: 48-50). This overall distribution of nationalities has not changed in a significant way since then.

Immigrants account for 8 percent of the total working population in Portugal (Almeida 2003). For the most part, they tend to work in the construction sector and in the bottom tier of the service economy, whether formal or informal (Fonseca 2005, Baganha 1996, Baganha, Ferrão and Malheiros 2002). Considering the compared structure of the national and foreign resident populations, the latter has a proportionally higher presence in the labour market (only 20 percent of foreigners in the country don't work, compared to 39 percent of nationals). With the exception of Cape Verdeans, foreigners are, however, more concentrated on low paid jobs than nationals, despite their higher level of education -- (Seabra and Santos 2005: 35). In addition to this economic integration into the lower ranks of the country's workforce, they also face harsher living conditions in terms of housing and work (Seabra e Santos 2005: 60). I will return to these social characteristics later on.

The chapter first examines disparities in offending rates and simultaneously presents explanations for the variations. Subsequently, it presents a case study drawing upon data from the author's fieldwork in a female prison to illustrate the intersections of ethnicity and class in offending, law enforcement response to offending, and the negotiation of identity within and outside the prison setting. 


\section{Offending Rates: A Comparison}

For the time being, it is important to keep in mind some of the above inequalities in order to interpret compared offending rates. ${ }^{5}$ A raw comparison between national and foreign residents seems to suggest a higher involvement of the latter in criminal behaviour ( 7 percent and 11 percent respectively), and thus could reinforce perceptions, popularized by the media, that associate immigration with criminality (Carvalheira 2008; see Vale de Almeida 2007 for discourses on difference). However, these numbers can be misleading and their meaning cannot be taken at face value, as they hide the distorting effect of different demographic structures. According to data from the more recent Census, ${ }^{6}$ foreign residents present an overall demographic structure which differs considerably from nationals'. Children and the elderly are under-represented among immigrants, whereas there is an over-representation of single young men. Once gender, age, and job-status are accounted for equally in the comparison between the two populations, offending rates are similar for national and non-national residents: 11 percent (Seabra and Santos, 2005: 118)

\section{From Court to Prison}

Foreigners are, however, over-represented behind bars (3 percent compared with 1 percent of nationals) as well as in the preceding stages of the crime control system ${ }^{7}$. It is nevertheless worth mentioning that this tendency appears to be modest when compared with the experiences of other countries of the European Union (EU25): Portugal stands fourth among those which present the lower over-representation of foreigners in the

\footnotetext{
${ }^{5}$ Several studies have contributed to contextualize this issue in Portugal: e.g. Barra da Costa 1999; Cunha 2002; Ferreira 1998; Lourenço and Lisboa 1998; Machado 2002; Pereira 1999; Rocha 2001, 2005; Seabra and Santos 2005; Baganha 1996; Baganha et al 2000).

${ }^{6}$ XIV Recenseamento Geral da População, Instituto Nacional de Estatística, 2001.

${ }^{7}$ For the statistical analysis of the imprisonment of foreigners in Portugal see Esteves 2001; Rocha 2001, 2005; Seabra and Santos 2005, 2006; Guia 2008.
} 
prison system (an over-representation measured by relation to the respective weight of foreigners within each country's resident population). Of the share of 18.5 percent of foreigners incarcerated in $2005^{8}$ (which is double the figure observed a decade earlier) in Portuguese prison facilities ${ }^{9}$, those of African nationalities, especially from lusophone countries (particularly Cape Verde and Angola), are still substantially in the majority (54.6 percent), even if their relative weight has declined in recent years in favour of an increase in the proportion of Europeans (25.8 percent) and Latin Americans (17.2 percent).

Sixty-six percent of the imprisoned foreigners had been resident in Portugal at the time of their arrest (Seabra and Santos 2006, Guia 2008), and the majority of those who did not had been convicted of drug trafficking (many of them drug couriers arrested at the airport). They were predominantly male, 33 years of age on average and they served prison sentences of slightly longer than six years ( 70 percent served prison sentences of between three and nine years). For reasons related to the circumstantial unavailability of alternative detention facilities (transit airport zones or specific shelters), a significant proportion (14 percent) of imprisoned foreigners waited behind bars, along with common criminals, an administrative decision that would expel them from the country, even though the undocumented/illegal presence within the borders is not criminalized by law.

Finally, studies which have tried to estimate the proportion of the Portuguese

\footnotetext{
${ }^{8}$ In the same year foreigners amount to 2386 in a universe of 12889 prisoners.

${ }^{9}$ I use here the general term prison for the 54 carceral institutions existing in Portugal, whether small local facilities, bigger central prisons or special prison facilities (prison-hospitals, carceral institutions for juveniles, and for women). Apart from the level of security, the distinction between detainee and convict is but one of the criteria for distributing inmates within the Portuguese prison system. But although there are no convicts serving long sentences in the closest Portuguese equivalent to jail (holding detainees or mostly those convicts sentenced to serve up to a year), people awaiting trial can be confined in prisons, especially when they are accused of serious crimes. The allocation of prisoners is initially based on the place where the offense was perpetrated and in which court it was tried. But after the sentence is issued, prisoners can request to be transferred to a prison closer to their family in order to make visits easier. Depending on the rate of occupation and the capacity of the requested prison, this is usually granted (see Abrunhosa Gonçalves 2007; Cunha 1994).
} 
gypsy ethnic minority behind bars have suggested to an average of between 5 percent and 6 percent of the inmate population (Moreira 1998, 1999). In the last two decades, the main criminal activities perpetrated by members of this community have shifted from property offenses (smuggling, petty thefts) to drug offenses, especially drug trafficking. ${ }^{10}$

The discrepancy between foreigners and nationals in the Portuguese criminal justice system has become especially salient since 1998, when there began to be a fall in both the total prison population of Portugal and also the number of Portuguese defendants. Over the same period in the case of foreigners, and particularly in relation to foreign women, the trend has been in the opposite direction. According to a study by Seabra and Santos (2005) that focused on the period between 1997 and 2003, the number of foreign defendants increased 118 percent, and the rise in the conviction rate has been proportionally much higher for foreigners ( 257 percent) than nationals (50 percent) (Seabra and Santos, 2005: 92). Also, the former were overall more likely to be convicted than the latter (81 percent of convictions in the case of foreign defendants, against 66 percent for Portuguese nationals). Other recent studies focus specifically on two more narrow periods of rapid increase: a rise of 67.4 percent between 1994 and 1996, and another of 50.8 percent between 2001 and 2005. The latter was strongly characterised by the rise of Eastern European prisoners, especially Ukrainians, Moldavians and Russians (Guia 2008; Moreira 2005).

As far as imprisonment is concerned, it is worth noting three facts in order to understand the disproportionate number of foreigners held behind bars. First, they are more likely to await trial in prison than Portuguese (in 20039 percent of foreigners but only 2 percent of Portuguese were remanded in custody). The fact that the proportion of

\footnotetext{
${ }^{10}$ For a compared characterization of gypsies's and non-gypsies's prison experiences, see Cunha (1994, 2002).
} 
foreigners in this situation who are acquitted is twice as high as the proportion of Portuguese nationals acquitted reinforces the supposition that their remand custody was all the more unjustified in the first place (Seabra and Santos, 2005: 80, 85). Second, foreigners in general are more likely to face a prison sentence than Portuguese and they have less access to alternative measures such as electronic surveillance. Third, foreigners are convicted to longer prison sentences than national citizens. Whereas in the period 1997-2003 national citizens amount to a proportion of less than 50 percent among the defendants sentenced to more than three years of firm (unsuspended) imprisonment, the proportion of foreigners receiving the same sentence stood at between 65 percent and 70 percent (Seabra and Santos 2005: 107).

As studies have pointed out in relation to other countries (for example, Tonry 1997), neutral legal reasons may contribute to these discrepancies. For example, among other reasons, remand custody is applied on the basis of the assessed risk of escape and/or the seriousness of the offense. In Portugal, in general it applies to an offense punishable by more than three years of imprisonment. But following specific procedural norms (Código do Processo Penal), judges deem the risk of escape to be higher in the case of foreigners, regardless of the seriousness of the offense. Furthermore, on the one hand it is true that like their Portuguese counterparts foreigners face trial mostly for road crimes (driving under influence of drink or drugs, driving without a license), drug offenses, and property offenses (assault, theft, larceny, and dub cheques) (Seabra and Santos 2005, 2006). On the other hand, however, foreigners are proportionately more concentrated than Portuguese precisely in the type of offenses which lead to higher conviction rates and harsher sentences - namely drug offences. This pattern is even more salient in the case of foreign women. Among the foreign men sentenced in the same year to a firm prison sentence, 48.9 percent were convicted for drug offences, 
compared to 27 percent in the case of nationals. With regard to their female counterparts, there were 61.1 percent of nationals against 85.6 percent of foreigners (Miranda Pereira 2005).

Even so, for the same offence - a drug offence for instance - and everything else being equal, the probability for a foreigner to be convicted to a prison sentence is significantly higher than for a national (in 2003, 86 percent against $65 \%$, Seabra and Santos 2005: 110)

Therefore, the over-representation of foreigners in the prison population seems to stem both from their greater involvement in crimes that are subject to more severe punishement (see also Pallida 1996; Tonry 1997) and from a tendency of the criminal justice system to punish foreign citizens more harshly (see also Tournier and Philippe 1991, Wacquant 1999b, 2005), even though the Portuguese Penal Code stresses the imperative of equal treatment for foreign and national prisoners.

\section{Deportation: A Double Punishment?}

But even if equal treatment were indeed applied to sentencing practices, there is nevertheless a sentencing measure which is aimed exclusively at foreigners, regardless of their resident status. This is the deportation sentence, whereby the convicted person may be compelled by a judicial decision to return to his/her country of origin - usually for a period of ten years. In the case of prisoners, this happens after they have served their prison sentence or immediately upon their release on parole (liberdade condicional). According to the Serviço de Estrangeiros e Fronteiras, which enforces the legislation regarding foreigners, the crimes that motivate the most deportation decision attached to a prison sentence are drug offenses, extortion, theft and robbery (see http://www.sef.pt). When non-residents are concerned, this deportation may be sought 
by the prisoners themselves even before the sentence of imprisonment is completed, insofar as they may prefer to serve their sentence closer to relatives and friends, and, in general, closer to their usual social environment. The two countries involved are then supposed to make the necessary arrangements to meet the prisoners' request in this matter. But when the object of this same measure is a long-time resident, it can have dramatic consequences for him/her and his/her family, as it implies a separation. Immigrants are thus subjected to what becomes a true exile, as the ties with the country of origin may have faded long ago.

But the deportation sentence has an additional collateral effect. Most of the time it impacts on the way foreign prisoners serve their sentences and may or may not benefit from the periodical leaves to which every prisoner is entitled to apply. Foreigners are often denied these leaves. They are refused to non-resident foreigners on the grounds that they would be useless insofar as they would not fulfil their reintegration purpose (Cunha 1994). From the first non-residents are presumed to lack social bonds in Portugal or a social world to which their reintegration should be fostered or secured. Residents, on the other hand, are denied such leaves not so much on the grounds of the risk of escape from prison per se, but because this risk is deemed to be higher when they are due to be deported upon their release (Cunha 2002).

\section{Imprisonment in a Foreign Land}

The absence of visitors or the scarcity of visits may also render the experience of imprisonment harsher for non-resident foreign prisoners. In an attempt to obviate this problem, the Portuguese Prison Administration tends to facilitate the transfer of some of these prisoners (especially Latin American) to the Funchal prison, in the island of Madeira, where they can be more easily visited by relatives, as travel is supposed to be 
less expensive and time consuming (Cunha 1994, Abrunhosa Gonçalves 2007). Otherwise, in general - continental Portuguese prisons included - regulations concerning visit days and visit schedules are applied in more flexible ways in the case of foreign visitors (Cunha 1994). Job access within prison can also be made easier to foreigners when they are deprived of the family support that would allow for the acquisition of in-prison consumer goods.

In the absence of family or NGO support, the assistance provided by embassies and consulates may take the form of essential goods and some financial support, in addition to other types of assistance such as the provision of legal representation and contacts with family members. In spite of the law (Código do Processo Penal, $\mathrm{n}^{\mathrm{o}} 2$ art. 92) that establishes the obligation of providing foreigners with an interpreter in court, lawyers have reported difficulties in rendering trials understandable to foreigners who do not speak Portuguese (in Público 2009). As far as the experience of confinement is concerned, until recently language differences have not, however, hindered severely daily communication or caused major difficulties as the majority of foreign prisoners have come from Portuguese-speaking countries. The present wider diversification of nationalities, especially with the arrival of North/East European prisoners, may have increased these problems, although English has also become a lingua franca used by more people, including nationals.

\section{Dynamics of Class and Ethnicity: A Case Study}

This section will draw on fieldwork that I conducted in the main women's Portuguese prison (Estabelecimento Prisional de Tires, EPT) on two different periods ${ }^{11}-$ to show

\footnotetext{
${ }^{11}$ I returned in 1997 to the Estabelecimento Prisional de Tires for a year-long fieldwork, a decade after a sojourn of two years in the same institution.
} 
the way ethnicity is framed and shapes sociality among prison inmates, a scenario illustrative of the negotiation of ethnicity beyond the narrow contours of the prison setting. It will focus on two aspects. First, the relative weakness of "race" and ethnicity as categories of identity and discourse, a weakness which partakes in a general dynamics of blurring boundaries between prisoners. Second, these categories are examined in light of their interplay with class, mediated by conditions such as the neighbourhood and the economy of retail drug markets. Such contextual meanings are all the more important to underline, insofar as: (i) categories of "race"/ethnicity are highly variable; (ii) a white/black dichotomy is not an analytical construct with universal contours, but a culturally specific one, and as such is not necessarily the best suited for post-colonial contexts such as Iberian ones (Pina Cabral 1998); ${ }^{12}$ (iii) when categories of "race"/ethnicity travel from one cultural context to another in scholarly discourse, they may arrive charged with an excessive voltage that short-circuits or obscures local dimensions of class (see in this light Cunha 2002 about Fikes 1998); and (iv) social identity and difference can be established without ethnic referents and class is not always subsumed in "race" in the same way as - say, for example -- in the USA. ${ }^{13}$ This is why it may be useful to specify these dimensions separately in order to be able to grasp their contextual interplay.

By the end of the 1990s, the overwhelming majority of inmates were incarcerated for drug offenses - thereby reducing the diversity of offenses that prevailed a decade earlier. ${ }^{14}$ In addition to this criminal homogeneity, there was also a social

\footnotetext{
${ }^{12}$ See in this light the debate in Theory, Culture and Society between Bourdieu and Wacquant (1999), and e.g. Friedman (2000), Hanchard (2003).

${ }^{13}$ Focusing on the semantic organization of these categories in what she calls American cultural discourse, Shirley Ortner points out that [T] here is no class in America that is not always already racialized and ethnicized, or, to turn the point around, racial and ethnic categories are already class categories (1998: 10).

${ }^{14}$ In January 1997, there were 820 prisoners in the main women's penitentiary of the country, mostly (69\%) serving sentences of more than 5 years. Seventy six percent were imprisoned for drug trafficking and $63 \%$ of those accused/convicted for property offenses were drug users.
} 
levelling at the bottom, which was apparent in a blatant impoverishment in respect of economic, social and educational capitals (Cunha 2002). Moreover, prisoners now came systematically from the same poor neighborhoods. Most of them were already known to each other before imprisonment, and they were connected by ties of friendship, neighborhood or kinship. ${ }^{15}$ Therefore, when behind bars they reproduced former relational circles. ${ }^{16}$ The reasons for this fact lie in the law enforcement agencies' selective targeting of specific socio-spatial categories, and in the structure of the Portuguese retail drug markets.

\section{The Neighborhood under Surveillance}

Retail drug trafficking came to induce specific patterns of repression in the penal system. It favored a pro-active style of law enforcement, which increased exponentially the potential for selectivity and bias. Police interventions were increasingly aimed at specific poor urban neighborhoods, which have become collective targets of surveillance and of routine indiscriminate sweeps. Under such intense police attention, the probability of arrest is higher in these territories. As in several other countries where drugs repression has reinforced similar styles of crime control (see, for example, Dorn et al, 1992; Duprez and Kokoreff, 2000), these stigmatized areas are now massive suppliers of prisoners.

Authors have reported that the arrest rates of members of ethnic/racial minorities are lower in the case of crimes in which investigation is triggered by a complaint from victims unaware of the perpetrator's ethnicity, than for those in which intervention rests

\footnotetext{
15 Between one half to two-thirds of the inmates shared Tires with family members (a conservative estimate based on data registered in social-educational files), and many more with neighbors or acquaintances: the prisoners originating from the two main metropolitan areas (78\%) came from the same neighborhoods ( $89 \%$ and $86 \%$ respectively), and similar patterns of concentration occurred within the remaining urban provenances.

${ }^{16}$ For the analytical implications of such clusters for prison studies, see Cunha (2008)
} 
mainly on police initiative (Smith 1997; Wilbanks 1987) - precisely the case of drug offenses. Other authors noticed that while the gaps between white and non-white arrest rates have narrowed overtime, the notorious exception remained with the arrests related to drugs, regardless of the evolution of offending patterns (see for example, Sampson and Lauritsen 1997 for the USA; see also a similar observation by Roberts and Doobs 1997 for Canada). Be it as it may, bias tends to be more salient at the frontline of the criminal justice system, more precisely in relation to proactive law enforcement. However, race/ethnicity per se may not be as decisive as it appears in determining police targets and they may operate indirectly, through other factors or in interaction with them. Studies indicate that police action tends to be triggered less by suspects' characteristics than the social status of residential areas considered as a whole. Even when the concentration of minorities is higher in poor urban areas, once inside these areas visible ethnicity ceases to be a predictor of police behavior (Jefferson 1993; Smith 1986).

\section{Ethnicity, Class, and the Retail Drug Economy in the Neighborhood}

In reference to the USA, Sampson and Lauritsen (1997: 400) stated that "By the nineties, 'race', class and drugs became intertwined. It is difficult, if not impossible, to disentangle the various elements of the problem". Portuguese urban neighborhoods are areas with a specific interplay between categories of "race"/ethnicity and class. They are socially and economically homogenous and ethnically diverse. While in Portugal minorities (mainly Gypsies and immigrants from lusophone African countries) are disadvantaged, they share this disadvantage - more than is the case in other countries with large segments of the white Portuguese population, for instance in the labor and the 
residential market (1992). ${ }^{17}$ Moreover, as the general socio-economic gap has widened, these same social segments of both minorities and non-minorities have found themselves further removed from more affluent segments of the population. To draw a brief comparison with other geographies, US inner-city neighborhoods tend to be racially/ethnically more uniform than European ones, where poverty tends to congregate more diverse populations in deprived urban areas (Wacquant 1995; Sampson and Lauritsen, 1997). But the Portuguese case presents additional specificities in relation to other destitute urban settings in Europe, where the poor are stratified along ethnic lines. An example of such infra-hierarchies, or stratifications among the poor, are previous blue-collar residents who resent deprived immigrant neighbors, perceiving their proximity as a sign of social demotion, or as an obstacle to social mobility (see for example, Althabe, 1993 and Sélim 1993 for France). In Portuguese low-income neighborhoods and in the few remaining shanty towns, poverty is more severe and survival is a priority for both minority and non-minority groups. Such urban settings are not usually the scene of similar symbolic struggles around upward or downward social trajectories. $^{18}$

The retail drug economy's inscription in poor urban neighborhoods reflects this same specific interplay between categories of "race"/ethnicity and class. Neighbors from different ethnicities take part side by side in the illegal - as well as legal economy. Race/ethnicity - anymore than gender (see Cunha 2005) - do not determine or restrict involvement in the local retail drug industry, which provides a relatively open

\footnotetext{
17 Analyzing census data, Machado concludes that:

In comparison with countries such as France, United Kingdom, Germany or Italy, in Portugal the social contrasts between 'third world' immigrant minorities and the national population are narrower, not so much because of a homogeneity in the class composition of minorities, a homogeneity which does not exist in their country of origin, but mainly because in Portugal the weight of ethnic minorities is lighter within the set of underprivileged social categories (1992: 128. My translation, emphasis in the original).

${ }^{18}$ This state of affairs is specific to this kind of urban settings and the peculiar conjunction of race/ethnicity and class as stated above. In other Portuguese contexts such struggles can be strong, not to mention the existence of racism, xenophobia, and anti-immigrant hostility. I am not implying, therefore, that, at the national scale, race/ethnicity do not generate social discrimination.
} 
illegal structure of opportunities. Unlike similar drug markets elsewhere in Europe and in the USA, which are ethnically stratified and where the lower, riskier and less rewarding segments of activity are left to a variety of minorities (Ruggiero and South 1995, 1996; Maher 1997), the Portuguese retail drug economy is indistinctly occupied by both minorities and non-minorities. At the bottom of the market, drug dealing has become one of the vectors of ethnic social levelling.

One of the reasons for this lies in the structure of the drug market. During the 1990s, a mutation in the structure of retail drug markets occurred not only in the USA but also in European contexts. Such markets had by that time adopted a business profile which (according to the typology proposed by Johnson, Hamid and Sanabria 1992), consists of vertically integrated organizations with a rigid centralized structure and involving crews of employees with almost no autonomy. Ruggiero and South (1995: 195) characterized similar structures in Europe as "crime in organization". Up until that decade the prevailing model was a different, more fluid, one. With little hierarchical interdependency or permanent wage relationships, a weak functional division of labor, it rested mostly on individual entrepreneurs. It was thus characterized as "free-lance" (Johnson, Hamid and Sanabria, 1992), or "crime in association" (Ruggiero and South (1995: 195). Even if free-lance markets shared the same gender ideologies and ethnic cleavages that filter access of potential participants to the drug economy in its more structured "business" format, ethnic and gender barriers were rendered much more permeable and inefficient by the very organizational fluidity of these markets. It is precisely the free-lance market structure that prevails in Portuguese retail drug economy, where the evolution has even been opposite to the one I have so far described for European and US contexts. That is, the business model evolved in the 1990s towards a free-lance one (Chaves 1999; Cunha 2007). 


\section{Ethnic Categorization Behind Bars}

This interplay between ethnicity and class mediated by local conditions such as the neighborhood and the economy of illegal drug markets helps to shed light on the fact that, in prison, "race" and ethnicity do not act as critical categories of identity or have a potential to organize social relations. Ethnic/racial referents are present in the prison vocabulary under the terms "white", "black", African, Cape-Verdean, Angolan, Gypsy and corrilha (non-Gypsy). However, in daily life these discursive categories have almost no salience. This was not the case in the 1980s, during my first fieldwork, when these categories were activated constantly. At that time, the stake was the collective denigration of some prisoners and two terms in particular were mobilized in this process: Gypsies and Cape-Verdeans. Elsewhere I have dealt with the first case (Cunha 2005), too complex to analyze here. I will stick to the latter in this chapter. The category of Cape-Verdean had a particularly flexible and contextual definition in the discursive practices of non-African prisoners, for whom the facts of nationality, origins, or place of birth seem to be highly irrelevant. Skin color sufficed as a criterion, and thus the majority of inmates of African origin were included in that category. Why subsume skin color in cape-verdeanity instead of the other way round, which would be more predictable an encompassment? That is, that Angolans, Guineans, Mozambicans... and Cape-Verdeans - would be classified for example as "blacks"? Because, I propose, the notion of Cape-Verdean was at the time well suited to stigmatize, or at least better suited to this effect than those tied to phenotype. The attribution which endowed the Cape-Verdean category with such a gravitational force was not alien to hegemonic perceptions that in the 1980 s isolated the Cape-Verdean community as a "problem" and identified it with a propensity to violence, delinquency and deviance (see for example, 
Rodrigues 1999: 63; Saint-Maurice 1997: xii). Given the overall in-prison stigmatizing dynamics that prevailed in carceral sociality at the time (see below), the term CapeVerdeans was appropriate to reinforce local strategies of demarcation and was readily integrated within them, as it carried in itself a disqualifying element.

This resonates with criminalization processes analyzed in the UK by Michael Keith (1993) as racializing discourses. In these processes, the category of black does not apply invariably and exclusively to a given parcel of the population which would thus be an object of racism. It would be, above all, a fluctuating subject created by the discourse of criminalization. The racial forms which result from such processes would be considerably mutable and contextual, and they would coexist and interact with those pertaining to other discursive fields. In that, Keith distances himself from standard labelling theories (see Becker 1963; Goffman 1975):

[I]t is important to differentiate between the notion of criminalization advanced here and standard labelling theory. A demographic fraction of society is not picked out and victimized. It is not so straightforward. A construction of criminality which draws on the glossary of racial difference is applied to define the varying subject positions of black communities at particular times and places (Keith 1993: 196)

In the same manner that Cape-Verdeans emerged, inside and outside prison, as a conspicuous discursive subject during the 1980s, so would they dissolve as such a decade afterwards. They were then replaced by other discursive "dangerous classes" (Chevalier 1984), that is, from now onwards, a categorization that amalgamated several ingredients: "blacks" (among which, Cape-Verdeans), Gypsies, drugs, and neighborhood-ghetto. In the 1990s, a small minority of middle-class white prisoners employed ethnic/racial labels in line with these new categorizations. For most prisoners, however, these notions did not impact in any way on daily sociality. An ethnic category did not generate, for example, preferential associations except those derived out of kinship; in addition, ritual kinship (godparents) is often inter-ethnic. More importantly, 
ethnic categories became merely descriptive and ceased to be instrumental in identity struggles. Even this relatively neutral descriptive use occurred mostly on occasions in which I took part as an interlocutor (as interviewer rather than observer) and for my benefit. Speaking of a friend or co-prisoner, an inmate could offer that "She's white like you". Given that the majority of the imprisoned population was nevertheless white, although poor and from the same stigmatized urban neighbourhoods as their non-white co-inmates, this was also a way to underline my social exteriority to this mixed universe.

It is important, however, to note that if in the 1980s "race" and ethnicity were relevant categories of identity and discourse in prison, they were so mostly in the same manner as other categories. In other words, they were among many other materials available for drawing boundaries, from someone's sexual orientation (same-sex relationships were stigmatized) to the crime which had led to their imprisonment (for example, whereas one's crime is always presented as a justifiable or an accidental single event, a co-prisoner's is usually identified as an expression of an unredeemable delinquent nature). Like in a mirror game of mutual oppositions, each inmate tried to conjure away her sensed stigmatized status (signified by the imprisonment itself) by disqualifying her co-inmates. "Race" and ethnicity did not therefore generate the social dynamics of mutual distancing. They merely took part in a dynamics that was already there.

A decade later, in the 1990s, these identity struggles had almost disappeared. Moreover, this absence of cleavages was for the first time voiced by the inmates themselves, who often took pride in stating that "we're all in the same boat, we're all equals - blacks, gypsies, everybody". There was now a sense of shared identity that was not alien to the new structural/class proximity - which was also a very tangible one, 
comprising pre-prison networks of neighborhood and kinship relations. ${ }^{19}$ It was as if integration within exclusion had occurred. Furthermore, the stigma which had been attached to prison in the 1980 s was from now on instituted prior to imprisonment, by the very fact of belonging to ill-reputed neighborhoods. And prison had already become a reality embodied in daily life in the neighborhood. Everybody had a friend, a neighbor or a relative who was or had been imprisoned at some time in the recent past. The symbolic boundary that the prison used to signify had also somehow eroded.

\section{Conclusion: crime, criminal justice and categories of difference}

How is 'difference', then, reflected on crime and the criminal justice system in Portugal? In the end, this seems indeed to be the adequate phrasing of the question addressed by this chapter. The kind of answers obtained depends on which local notions we can translate 'difference' into: 'race', 'ethnicity', 'foreigners', 'immigrants', 'minorities'. This, in turn, depends also on whether we focus on statistics, rates, or, from another angle, experiences of crime and of the criminal justice system.

Quantitative and qualitative data highlight different but complementary aspects of a same landscape.

Portuguese official statistics allow for grasping the 'difference' mentioned above only in terms of the pair: foreigners/citizens, regardless of race or ethnicity.

As far as offending rates are concerned, raw numbers indicate a discrepancy between national and foreign residents. These numbers neglect, however, the respective demographic structures, and, in particular, the over-representation of single young men

\footnotetext{
${ }^{19}$ Not incidentally, this discursive playing down of racial/ethnic categories was also reported for poor ethnically mixed neighborhoods (Saint-Maurice 1997; Rodrigues 1990). For a more detailed analysis see Cunha (2002).
} 
among immigrants. The discrepancy disappears once gender, age, and job-status are accounted for equally in the comparison between the two populations.

Notwithstanding this, the discrepancy reappears in every stage of the crime control system, and foreigners end up over-represented behind bars.

This stems both from a tendency of the criminal justice system to punish foreigners more harshly and from the fact that the latter are proportionately more concentrated than Portuguese on the offenses which motivate higher conviction rates and harsher sentences - namely, drug offences. This pattern becomes even clearer when foreigners are women

This overall discrepancy has widened since the second half of the 1990s. In that same period, I conducted an ethnographic study in a women's prison where drug offenses stood out as a major cause of imprisonment. This study allowed for the highlighting of the way categories of difference which are excluded from the official statistics - that is, race and ethnicity, regardless of national/foreigner citizenship status - may be at play in crime, law enforcement, and the experience of imprisonment.

In all three domains class and the nature of residential areas emerge as important conditions for the relevance of race and ethnicity. This relevance is also determined, at another level, by the open structure of local drug markets, which provides "equal opportunities" to different ethnicities. Portuguese retail drug economy is indistinctly occupied by both minorities and non-minorities. Furthermore, the Portuguese urban neighbourhoods where the retail drug economy takes hold present a specific interplay between categories of race/ethnicity and class. Poverty congregates ethnically diverse populations in a uniform position. Given a socioeconomic gap that had widened over 
the course of the preceding decade, segments of both minorities and non-minorities have found themselves further removed from more affluent segments of the population.

It is this changing intersection between ethnicity and class, mediated by conditions such as the neighbourhood and the workings of the drug economy, that now helps to prevent, in prison, strong expressions of race and ethnicity as categories of identity and social organization. Categories of difference have changed between the 1980s and 1990s, as has the definition of 'dangerous classes' by criminalization discourses that draw on the glossary of difference.

\section{References:}

Abrunhosa Gonçalves, R. (2007), Portugal, in A. M. Van Kalmthaut, F. B. A. M. Hofstee-van der Meulen, F. Dünkel (eds.), Foreigners in European Prisoners, vol. 2, The Netherlands, Wolf Legal Publishers: 691-709.

Almeida, A. C. (2003), Impacto da Imigração em Portugal nas Contas do Estado, Lisbon, Alto Comissariado para a Imigração e Minorias Étnicas.

Althabe, G. (1993), "La Résidence Comme Enjeu", in G. Althabe et al (eds.), Urbanisation et Enjeux Quotidiens. Terrains Ethnologiques dans la France Actuelle, Paris, L'Harmattan: pp. 11-69.

Baganha, M. I. (1996), Migrants Insertion in the Informal Economy, The Portuguese Case, First Report. Coimbra: CES - Universidade de Coimbra.

Baganha, M. I., Marques, J. C. and Fonseca, Graça F. (2000), Is an Ethniclass Emerging in Europe? The Portuguese Case. Lisboa: Fundação Luso Americana.

Baganha, M. I. and Marques, J. C. (2001), "A Cada Sul o seu Norte. Dinâmicas Migratórias em Portugal", in B. Sousa Santos (ed.), Globalização. Fatalidade ou Utopia? Porto, Afrontamento: 135-159.

Baganha, M. I., Ferrão, J. and Malheiros, M. (eds.) (2002), Os Movimentos Migratórios Externos e a Sua Incidência no Mercado de Trabalho em Portugal, Colecção 'Estudos e Análises', 14, Lisbon, Observatório do Emprego e Formação Profissional. 
Barra da Costa, J. M. (1999), Práticas Delinquentes, De Uma Criminologia Do Anormal A Uma Antropologia Da Marginalidade, Edições Colibri, Lisboa.

Becker, H. (1963), Outsiders, New York, Free Press.

Bourdieu, P. and Wacquant, L. (1999), On the Cunning of Imperialist Reason, Theory, Culture and Society, 16 (1): 41-58.

Código de Processo Penal Português, Decreto-Lei n. 78/87, de 17 de Fevereiro.

Cabecinhas, R. (2007), Preto e Branco. A Naturalização da Discriminação Racial, Porto, Campo das Letras.

Carvalheira, J. R. (2008), Do Bidonville ao Arrastão. Media, Minorias e Etnicização, Oeiras, Celta.

Chaves, M. (1999), Casal Ventoso: Da Gandaia ao Narcotráfico, Lisboa, Imprensa de Ciências Sociais.

Chevalier, L. (1984) [1978], Classes Laborieuses et Classes Dangereuses à Paris, Pendant la Première Moitié du XIX Siècle, Paris, Hachette.

Crucho de Almeida, M. R. (1995), Inquérito à Vitimação 1994. Lisboa: Gabinete de Estudos e Planeamento do Ministério da Justiça.

Crucho de Almeida, M. R. (1998), Vitimação e insegurança no Concelho de Lisboa. Lisboa: Gabinete de Estudos e Planeamento, Ministério da Justiça.

Cunha, M. P. da (1994), Malhas que a Reclusão Tece. Questões de Identidade numa Prisão Feminina, Lisboa, Cadernos do Centro de Estudos Judiciários.

Cunha, M. P. da (2002), Entre o Bairro e a Prisão: Tráfico e Trajectos. Lisbon : Fim de Século.

Cunha, M. P. da (2005a), "From Neighborhood to Prison. Women and the War on Drugs in Portugal", in Julia Sudbury (ed.) Global Lockdown. Race, Gender, and PrisonIndustrial Complex. NewYork: Routledge:155-165.

Cunha, M. P. da (2005b), "Les gitans, la prison et le quartier: d'une relation spécifique devenue le modèle ordinaire", Études Tsiganes, n 21: pp. 34-47.

Cunha, M. P. da (2007) "Les liens du trafic: parenté, voisinage et genre dans des narcomarchés", in M. Kokoreff, M. Péraldi and M. Weinberger (eds.), Économies criminelles et mondes urbains, Paris, PUF : pp. 109-119.

Cunha, M. P. da (2008), "Closed Circuits: Kinship, Neighborhood and Imprisonment in Urban Portugal”, Ethnography, vol. 9, no 3: 325-350.

Dorn, N., Murji, K. and South, N. (1992), Traffickers. Drug Markets and Law Enforcement, London, Routledge. 
Duprez, D. and Kokoreff, M. (2000), Les mondes de la Drogue, Paris, Odile Jacob.

Esteves, A. and Malheiros, J. M. (2001), "Os Cidadãos Estrangeiros nas Prisões Portuguesas", in Magda Pinheiro, Luís V. Baptista and Maria João Vaz (eds.), Cidades e Metrópole. Centralidades e Marginalidades, Oeiras, Celta.

Ferreira, E. V. (1998), Crime e insegurança em Portugal, padrões e tendências, 19851996, Oeiras: Celta.

Fikes, K. (1998), "Domesticity in Black and White: Assessing Badia Cape Verdean Challenges to Portuguese Ideals of Black Womanhood”, Transforming Anthropology, vol. $7, n^{\circ} 2$ : pp. 5-19.

Fonseca, L. (2005) Migrações e Território, Lisbon, Centro de Estudos Geográficos, Universidade de Lisboa.

Friedman, J. (2000), “Americans Again, or the New Age of Imperial Reason?”, Theory, Culture and Society, 17 (1): 139-146.

Gersão, E. and Lisboa, M. (1994), "The Self Report Delinquency Study in Portugal”, in J. Junger-Tas, Gert-Jan Terlouw and Malcom W. Klein, Delinquent Behaviour Among Young People in the Western World. First Results of the International Self-Report Delinquency Study, Studies on Crime and Justice, The Dutch Research and Documentation Centre, RDC - Ministry of Justice. pp. 212-237.

Guia, M. J. (2008), Imigração e Criminalidade. Caleidoscópio de Imigrantes Reclusos, Coimbra, Almedina.

Goffman, E. (1975) [1963], Stigmate. Les Usages Sociaux des Handicaps, Paris, Minuit.

Hanchard, M. (2003), "Acts of Misrecognition: Transnational Black Politics, AmtiImperialism and the Ethnocentrisms of Pierre Bourdieu and Loïc Wacquant", Theory, Culture and Society, 20 (4): 5-29.

Jefferson, T. (1993), "The Racism of Criminalization: Policing and the Reproduction of the Criminal Other", in L. Gelsthorpe and W. McWilliam (eds.), Minority Ethnic Groups and the Criminal Justice System, Cambridge, University of Cambridge Institute of Criminology.

Johnson, B., Hamid, A. and Sanabria, H. (1992), "Emerging Models of Crack Distribution", in T. Mieczkowski (ed.), Drugs, Crime, and Social Policy: Research, Issues, and Concerns, Boston, Allyn and Bacon: pp. 56-78.

Lourenço, N. and Lisboa, M. (1998), Dez Anos de Crime em Portugal. Análise Longitudinal da Criminalidade Participada às Polícias (1984-1993). Caxias: Gabinete de Estudos Jurídico-Sociais do Centro de Estudos Judiciários.

Machado, F. L. (1992), "Etnicidade em Portugal. Contrastes e Politização”, Sociologia. 
Problemas e Práticas, n 12: pp. 123-136.

Machado, F. L. (2002), Contrastes e Continuidades. Migração, Etnicidade e Integração dos Guineenses em Portugal, Oeiras: Celta.

Maher, L. (1997), Sexed Work. Gender, Race and Resistance in a Brooklyn Drug Market, Oxford, Clarendon Press.

Moreira, J. J. S. (1998), “Ciganos na Prisão. Um Universo Diferente?”, Temas Penitenciários, II Série, 2: 5-18.

Moreira, J. J. S. (1999), "Ciganos em Privação de Liberdade”, Revista do Ministério Público, $\mathrm{n}^{\circ}$ 77: pp. 59-88.

Moreira, J. J. S. (2005), Estatísticas Prisionais - 2005. Apresentação e Análise. Lisbon, Direcção Geral dos Serviços Prisionais.

Ortner, S. (1998), "Identities: The Hidden Life of Class", Journal of Anthropological Research, vol. 54, n 1: pp. 1-17.

Pallida, S. (ed.) (1996), Délit d’Immigration/Immigrant Delinquançy, Brussels, European Commission.

Pena Pires, R. (2003), Migrações e Integração, Oeiras, Celta.

Pereira, Á. P (1999), "Prisões: decidir ou conhecer", in Helena Carreiras, Fátima Freitas and Isabel Valente (eds.), Profissão Sociólogo, Celta Editora, Oeiras.

Pina Cabral, J. (1998), "Racismo ou Etnocentrismo?", in H. Gomes de Araújo et al. (eds.), Nós e os Outros. A Exclusão em Portugal e na Europa, Porto, Sociedade Portuguesa de Antropologia e Etnologia: 19-26.

Público (Jornal) (2009), "Estrangeiros têm mais dificuldade em defender-se", Terçafeira, 24 de Fevereiro: 6.

Roberts, J. and Doob, A. (1997), "Race, Ethnicity and Criminal Justice in Canada", in M. Tonry (ed.), Ethnicity, Crime and Immigration, Chicago, University of Chicago Press: pp. 469-522.

Rocha, J. L. M. (2001), Reclusos Estrangeiros. Um Estudo Exploratório, Coimbra, Almedina.

Rocha, J. L. M. (ed.) (2005), Entre a Reclusão e a Liberdade. Estudos Penitenciários, Coimbra, Almedina.

Rodrigues, W. (1990), "Minorité Cap-Verdienne: Espaces, Identités et Processus de Marginalisation", Sociedade e Território, Setembro, nº especial: pp. 63-67.

Ruggiero, V. and South, N. (1995), Eurodrugs. Drug Use, Markets and Trafficking in Europe, Londres, UCL Press. 
Ruggiero, V. and South, N. (1996), "La Ville de la Fin de l'Ère Moderne en Tant que Bazar: Marchés de Stupéfiants, Entreprise Illégale et les Barricades", Déviance et Société, vol. 20, nº 4: pp. 315-333.

Saint-Maurice, A. de (1997), Identidades Reconstruídas. Cabo-Verdianos em Portugal, Oeiras, Celta.

Sampson, R. J. and Lauritsen, J. L. (1997), "Racial and Ethnic Disparities in Crime and Criminal Justice in the United States" in M. Tonry (ed.), Ethnicity, Crime and Immigration - Comparative and Cross-national Perspectives, The University of Chicago Press, Chicago and London: 311-376.

Seabra, H. M. and Santos, T. (2005), A Criminalidade de Estrangeiros em Portugal. Um Inquérito Científico, Lisbon, Alto Comissariado para a Imigração e Minorias Étnicas.

Disponível on line

Seabra, H. M. and Santos, T. (2006), Reclusos Estrangeiros em Portugal. Esteios de uma Problematização, Lisbon, Alto Comissariado para a Imigração e Minorias Étnicas. Disponível on line

Sélim, M. (1993), "Une Cohabitation Pluri-Ethnique”, in G. Althabe et al, Urbanisation et Enjeux Quotidiens. Terrains Ethnologiques dans la France Actuelle, Paris, L'Harmattan: pp. 71-111.

Smith, D. (1997), "Ethnic Origins, Crime and Criminal Justice" in M. Maguire, R. Morgan and R. Reiner (eds): The Oxford Handbook of Criminology, Oxford, Clarendon Press: pp. 703-759.

Smith, D. (1986), "The Neighborhood Context of Police Behavior", in A. Reiss and M. Tonry (eds.), Communities and Crime, Chicago, University of Chicago Press.

Tonry, M. (1997), "Ethnicity, Crime and Immigration" in M. Tonry (ed.), Ethnicity, Crime and Immigration - Comparative and Cross-national Perspectives, The University of Chicago Press, Chicago and London: 1-29.

Tournier, P. and Philippe R. (1991), Etrangers et Délinquances, Les Chiffres du Débat, Logiques Sociales, Paris, L'Harmattan.

Vale de Almeida, M. (2007), "On Difference and Inequality: The Lessons of Ethnographic Experience", in António Pinto Ribeiro (ed.), The Urgency of Theory, Manchester, Carcanet \& Fundação Calouste Gulbenkian: 44-78-

Wacquant, L. (1995), "The Comparative Structure and Experience of Urban Exclusion: Race, Class and Space in Paris and Chicago, in K. McFate et al. (eds.), Poverty, Inequality, and the Future of Social Policy: Western States in the New Orld Order, New York, Russell Sage Foundation: pp. 542-570.

Wacquant, L. (1999a), Les Prisons de la Misère. Paris: Raisons d'Agir Éditions. 
Wacquant, L. (1999b), "Suitable Enemies. Foreigners and Immigrants in the Prisons of Europe", Punishment and Society, 10 (2): 215-222.

Wacquant, L. (2005), “Enemies of the Wholesome Part of the Nation'. Postcolonial Migrants in the Prisons of Europe", Sociologie, I: 31-51.

Willbanks, W. (1987), The Myth of a Racist Criminal Justice System, Monterey, California, Brooks/Cole.

Manuela Ivone Cunha

micunha@ics.uminho.pt

Centro em Rede de Investigação em Antropologia - Universidade do Minho (Portugal); Institut D’Ethnologie Méditerranéenne, Européenne et Comparative (France) 